\title{
Susceptibility of parent and interspecific F1 hybrid pine trees to tip moth damage in a coastal North Carolina planting
}

\author{
Maxine T. Highsmith, John Frampton, David O'Malley, James Richmond, and \\ Martesa Webb
}

\begin{abstract}
Tip moth damage among families of parent pine species and their interspecific F1 hybrids was quantitatively assessed in a coastal planting in North Carolina. Three slash pine (Pinus elliotti var. elliotti Engelm.), two loblolly pine (Pinus taeda L.), and four interspecific F1 hybrid pine families were used. The F1 hybrids were as susceptible to damage by Nantucket pine tip moth (Rhyacionia frustrana (Comst.)), as was their susceptible loblolly pine parent. Their phenotypes support a dominant or partially dominant mode of inheritance for susceptibility. The phenotype of one slash pine family was not statistically different from the phenotypes of the loblolly and F1 hybrid pines. The high susceptibility of that one slash pine family appeared to be intrinsic, even though slash pine is considered resistant to tip moth damage. Tip moth damage on the two other slash pine families was significantly lower.
\end{abstract}

\begin{abstract}
Résumé : Les dommages causés par le perce-rameau du pin parmi les familles d'espèces de pin, chez les parents et leurs hybrides interspécifiques F1, ont été mesurés dans une plantation côtière de la Caroline du Nord. Trois familles de pin de Floride (Pinus elliotti var. elliotti Engelm.), deux familles de pin à encens (Pinus taeda L.) et quatre familles d'hybrides interspécifiques F1 ont été utilisées. Les hybrides F1 étaient aussi susceptibles aux dommages causés par le perce-rameau du pin (Rhyaciona frustana (Comst.)) que leurs parents également susceptibles. Leur phénotype possède un mécanisme d'héritabilité dominant ou partiellement dominant pour la susceptibilité. Le phénotype d'une famille de pin de Floride n'était pas statistiquement différent des phénotypes des pins à encens et des hybrides F1. La susceptibilité élevée de cette famille de pin de Floride apparaissait intrinsèque, même si le pin de Floride est considéré comme résistant au perce-rameau. Les dommages causés par le perce-rameau étaient significativement plus faibles sur les deux autres familles de pin de Floride.
\end{abstract}

[Traduit par la Rédaction]

\section{Introduction}

Pine tip moths (Rhyacionia spp.) are insect herbivores that feed on Pinus spp. seedlings worldwide and can be serious pests, especially in commercial pine plantations. Female tip moths oviposit on the shoots and needles of several species of southern pines. Developing larvae kill the shoot tips of seedlings $\leq 5$ years old, reducing growth and productivity but rarely causing mortality (Berisford and Ross 1990; Berisford 1988; Yates and Beal 1971).

The long-term impact of tip moth damage to pine trees is a reduction in stem diameter and, therefore, volume (Cade and
Hedden 1987). For example, loblolly pines (Pinus taeda L.) that were planted on a low-quality site and protected against tip moth infestation after 12 years produced $28 \%$ more volume than unprotected trees on the same site (Cade and Hedden 1987). Similarly, Stephen et al. (1982) reported that after 20 years, loblolly pines in Arkansas that were protected against tip moth infestation produced $23 \%$ more volume than unprotected trees.

Rhyacionia frustrana (Comst.) (Lepidoptera: Olethreutidae), the Nantucket pine tip moth (NPTM), causes more damage to pine trees in the southeastern United States than any other tip moth species (Berisford 1988). Its host range includes all

Received August 8, 1999. Accepted January 12, 2001. Published on the NRC Research Press Web site on May 17, 2001.

M.T. Highsmith. ${ }^{1}$ Department of Natural and Physical Sciences Shaw University, Raleigh, NC 27601, and Department of Forestry, North Carolina State University, Raleigh, NC 27695, U.S.A.

J. Frampton, and D. O'Malley. Department of Forestry, North Carolina State University, Raleigh, NC 27695, U.S.A.

J. Richmond. ${ }^{2}$ Department of Biology, North Carolina Central University, Durham, NC 27707, U.S.A.

M. Webb. Department of Natural and Physical Sciences, Shaw University, Raleigh, NC 27601, U.S.A.

${ }^{1}$ Corresponding author (e-mail: mhismith@bellsouth.net).

${ }^{2}$ USDA Forest Service, Southern Research Station, Asheville, N.C. Retired. 
Table 1. Name and description of four tip moth damage traits assessed on a pine field study in Beaufort County, North Carolina.

\begin{tabular}{ll}
\hline Trait name & Description \\
\hline Leader incidence 1 & Percentage of trees with damaged terminal leaders after one growing season \\
Leader incidence 2 & Percentage of trees with damaged terminal leaders after two growing seasons \\
Lateral incidence 1 & Percentage of trees with at least one damaged lateral branch after one growing season \\
Cumulative incidence & Percentage of trees with any (terminal or lateral) leader damage during the first and (or) second growing season(s) \\
\hline
\end{tabular}

but two species of southern pines. Loblolly pine, shortleaf pine (Pinus echinata Mill.), and Virginia pine (Pinus virginiana Mill.) are all susceptible. Slash pine (Pinus elliotti var. elliotti Engelm.) is considered highly resistant to NPTM damage, and field-grown longleaf pine (Pinus palustris Mill.) is not considered to be a host (Berisford and Ross 1990; Wakeley 1928).

A few studies have used loblolly and slash pines to examine NPTM oviposition behavior in mixed plantings of susceptible and resistant trees, and the authors of those studies have offered hypotheses to explain the differential in the species' susceptibilities. For example, Yates (1966) concluded that female tip moths randomly oviposit on loblolly and slash pines followed by slower growth and greater mortality of the larvae on slash pine. He suggested that a slower rate of resin crystallization in slash pines might be the cause. On the other hand, Hood et al. (1985) concluded that the NPTM females preferentially oviposit on loblolly pines. They suggested that the difference might result from chemical, tactile, and (or) visual cues in the pine trees. Ross et al. (1995) found that levels of the monoterpene myrcene were significantly higher in loblolly than in slash pine (10.9 vs. $3.3 \%$ ). They suggested that NPTM females might use the difference in myrcene levels to distinguish between the two for oviposition.

Recently, Fritz et al. (1994, 1996) used interspecific F1 hybrids to examine the inheritance of resistance to insect damage and disease in willow trees. Insight into how F1 hybrid pines inherit susceptibility or resistance to tip moth damage could provide clues leading to a better understanding of differential tip moth damage among pine species. To quantitatively assess such damage, this study used a controlled experimental field design to compare NPTM damage among families of parent pine species and their interspecific F1 hybrids.

\section{Materials and methods}

\section{Plant material}

Cuttings were collected from two open-pollinated loblolly pine families (L1, L2), three open-pollinated slash pine families (S1, S2, S3), and four interspecific loblolly $\times$ slash F1 hybrid pine families $(\mathrm{L} 1 \times \mathrm{S} 1, \mathrm{~L} 1 \times \mathrm{S} 2, \mathrm{~L} 1 \times \mathrm{S} 3, \mathrm{~L} 1 \times \mathrm{S} 4)$. The $\mathrm{F} 1$ hybrid pines were from controlled pollinations that used slash pines as the pollen parent. The slash pine pollen and open-pollinated seeds were from an established orchard in Rincon, Ga., and the openpollinated loblolly pine seeds were from an established orchard in Washington, N.C. The slash pine parent family (S4) was not used in this study.

Several cuttings of each of the nine families were collected from hedges in an orchard located near Comfort, N.C., and rooted in a propagation greenhouse in Hot Springs, Ark. (Frampton and Huber 1995). The hedge orchard near Comfort, N.C., is a facility where stock plants are sheared and managed cuttings are produced.
On September 23, 1991, a portion of the rooted cuttings was used to establish this study in a field in Beaufort County near the North Carolina coast. The cutover area was operationally siteprepared, bedded, and fertilized with phosphorus prior to planting. After plantation establishment, herbicides were applied as needed during the 2-year course of this study to reduce weed competition.

\section{Experimental design}

The study was a randomized complete block design. Each of 5 blocks contained a 30-tree plot of each of the 9 families, arranged in 2 rows of 15 trees each for a total of 1350 trees. Clonal identity was not tracked within families, but clonal replication was low (no more than three or four ramets per clone) and was randomized throughout the study. A border row was established around the entire 4.3 -acre $(1$ acre $=0.405$ ha) study.

\section{Damage assessment}

Tip moth damage was assessed during the winter following the pine trees' first and second growing seasons, where a "season" refers to growth within a period of a year. Damage from all (three or four) of the year's tip moth generations was complete, and pupae were overwintering in shoot tips at the end of each growing season. Damage was assessed by visual inspection of leader and lateral terminal shoots. Shoots with characteristic browning, curling, crystallized resin, and (or) shoot dieback were scored as damaged. Damage was recorded as present or absent in terminal leader shoots at the end of both growing seasons and in the lateral terminal shoots at the end of the first growing season only. Adult and pupae tip moth samples were periodically collected and identified as to species to verify that the damage was essentially due to NPTM.

Four tip moth damage traits were calculated based on block means: leader incidence 1, leader incidence 2, lateral incidence 1, and cumulative incidence. Leader incidence 1 and leader incidence 2 were measured in terminal leader shoots after the first and second growing seasons, respectively, and lateral incidence 1 in lateral terminal shoots after the first season only. These traits (leader incidence 1 , leader incidence 2, and lateral incidence 1) were combined to produce the cumulative incidence trait (Table 1).

\section{Statistical analyses}

Pearson's correlation coefficients and means among families were calculated for the four tip moth damage traits. Principal component analysis (not shown) was also performed using the four traits to further investigate relationships and redundancies among them. They all "loaded on" to one component with the bivariate correlation between cumulative incidence and the component being greatest (0.93). Based on these analyses, cumulative incidence was selected as the most appropriate trait for further analyses. Although this trait represents percentage data, a Shapiro-Wilk test suggested no departure from normality ( $W=0.9829, P=0.7013$ ); thus, the data were not transformed. The block means for this trait were subjected to an analysis of variance with block, species, and family (species) serving as sources of variation. The mean square error for this model had 32 degrees of freedom. Least squares means for species and family(species) were calculated and compared with pairwise $t$ tests (SAS Institute Inc. 1990). Tests were considered 
Table 2. Overall mean and correlations among family means for Nantucket pine tip moth damage traits assessed on a pine field study located in Beaufort County, North Carolina.

\begin{tabular}{|c|c|c|c|c|}
\hline & \multirow[b]{2}{*}{ Mean $(\%)$} & \multicolumn{3}{|l|}{ Correlations* } \\
\hline & & Leader incidence 1 & Leader incidence 2 & Lateral incidence 1 \\
\hline Leader incidence 1 & 35.7 & & & \\
\hline Leader incidence 2 & 13.6 & $0.70(0.04)$ & & \\
\hline Lateral incidence 1 & 53.7 & $0.64(\mathrm{~ns})$ & $0.71(0.03)$ & \\
\hline Cumulative incidence & 32.0 & $0.95(0.0001)$ & $0.81(0.008)$ & $0.76(0.02)$ \\
\hline
\end{tabular}

Table 3. Species least squares means and results of pairwise $t$ test comparisons for the cumulative incidence of tip moth damage after the second growing season in a pine field study located in Beaufort County, North Carolina.

\begin{tabular}{llll}
\hline & Least squares & \multicolumn{2}{c}{$\begin{array}{l}P>|t| \text { for } \mathrm{H}_{0}: \text { row and column } \\
\text { family means are equal }\end{array}$} \\
\cline { 4 - 4 } Species & mean & Loblolly & Hybrid \\
\hline Loblolly pine & 78.2 & $\mathrm{~ns}^{*}$ & \\
Hybrid & 69.0 & 0.0001 & 0.002 \\
Slash pine & 53.3 &
\end{tabular}

statistically significant if differences were detected at the $P<0.05$ level.

\section{Results}

Pearson correlations among family means for the four traits, leader incidence 1, leader incidence 2, lateral incidence 1, and cumulative incidence, were positive and significant. (Table 2). The highest correlation among these traits involved cumulative incidence.

The average incidence of tip moth damage in terminal leader shoots decreased from $35.7 \%$ in the first year to $13.6 \%$ in the second. Incidence of tip moth damage in lateral terminal shoots was $53.7 \%$ at the end of the first growing season (Table 2).

The cumulative incidence of tip moth damage among species and families was significantly different. A comparison of species showed that $78.2 \%$ of loblolly pines and $69.0 \%$ of F1 hybrid pines had tip moth damage versus $53.3 \%$ for slash pines (Table 3 ). The cumulative incidence of tip moth damage in the F1 hybrids was not significantly different from that of the loblolly pines. However, both the F1 hybrids and loblolly pines had cumulative incidences of damage that were significantly different from that of slash pine (Table 3 ).

A comparison of the cumulative incidence of tip moth damage among families showed that the loblolly pines, L1 and L2, were not significantly different with 78.7 and $77.7 \%$ damage, respectively (Table 4). Similarly, there was no difference in the F1 hybrid families with respect to cumulative incidences of tip moth damage, which ranged in values from 64.8 to $72.5 \%$. The cumulative incidence of tip moth damage in the F1 hybrids was also not statistically different from that of the loblolly pines.

For the S1 slash pine family, the cumulative incidence of tip damage was $66.9 \%$ and not significantly different from that of the loblolly and F1 hybrid pine families. The two re- maining slash pine families, S2 and S3, had significantly lower cumulative incidences of damage (48.4 and $44.5 \%$, respectively; Table 4).

\section{Discussion}

Pearson correlations (Table 2) and principal component analysis results (not shown, see Statistical analyses above) suggest that the four traits of tip moth damage, leader incidence 1 , leader incidence 2 , lateral incidence 1 and cumulative incidence, measure the same biological mechanism relative to tip moth damage. Based on those analyses, the best measure of that mechanism is the cumulative incidence of tip moth damage. We recommend the cumulative incidence approach to assessing tip moth damage, but it could be improved by assessing damage in terminal leader and (or) lateral shoots for more years than was done in this study. However, the cumulative results over the two infestation periods in this study provided a better and more accurate assessment of the pattern of tip moth damage among the trees than that of either period individually.

Overall, the cumulative incidence of tip moth damage for the F1 hybrids was statistically the same as that of the susceptible parent species and different from that of the resistant parent species. Two earlier studies made similar reports. Sondregger pine, a natural F1 hybrid of longleaf and loblolly pines, was reported to be just as susceptible to tip moth damage as its susceptible loblolly pine parent (Chapman 1922). Also, F1 hybrids of shortleaf and slash pines were reported to be as susceptible to tip moth damage as their susceptible shortleaf parents (Grano and Grigsby 1968). Collectively, these studies suggest a dominant mode of inheritance for susceptibility at the species level. In this present study, when the two relatively resistant slash pine parent families, S2 and S3, were crossed with the susceptible loblolly pine parent, L1, the resulting F1 hybrid families were as susceptible as was the susceptible parent. This data further supports a dominant mode of inheritance for susceptibility at the individual tree level.

While the interpretation of these data is congruous with other reports, caution is in order. The number of families tested in this study is very low, and in fact, only one loblolly pine tree was involved in the hybrid crosses. Obviously a larger sample size must be examined before confidently extrapolating these results to larger populations. Also, while cumulative incidence in the F1 hybrids is not statistically different from that of their susceptible loblolly pine parent, there is an incremental difference ranging from 6.2 to $13.9 \%$ that intimate that partial rather than full dominance may be operating. Clearly, however, an additive genetic model for 
Table 4. Family least squares means and results of pairwise $t$ test comparisons for the cumulative incidence of tip moth damage after the second growing season in a pine field study located in Beaufort County, North Carolina.

\begin{tabular}{|c|c|c|c|c|c|c|c|c|c|}
\hline \multirow[b]{2}{*}{ Family } & \multirow[b]{2}{*}{ Mean } & \multicolumn{8}{|c|}{ Least squares $P>|t|$ for $\mathrm{H}_{0}$ : row and column family means are equal } \\
\hline & & L1 & L2 & $\mathrm{L} 1 \times \mathrm{S} 1$ & $\mathrm{~L} 1 \times \mathrm{S} 2$ & $\mathrm{~L} 1 \times \mathrm{S} 3$ & $\mathrm{~L} 1 \times \mathrm{S} 4$ & $\mathrm{~S} 1$ & $\mathrm{~S} 2$ \\
\hline L1 & 78.7 & & & & & & & & \\
\hline L2 & 77.7 & ns* & & & & & & & \\
\hline $\mathrm{L} 1 \times \mathrm{S} 1$ & 64.8 & ns & ns & & & & & & \\
\hline $\mathrm{L} 1 \times \mathrm{S} 2$ & 72.4 & ns & ns & ns & & & & & \\
\hline $\mathrm{L} 1 \times \mathrm{S} 3$ & 66.3 & ns & ns & ns & ns & & & & \\
\hline $\mathrm{L} 1 \times \mathrm{S} 4$ & 72.5 & ns & ns & ns & ns & ns & & & \\
\hline S1 & 66.9 & ns & $\mathrm{ns}$ & $\mathrm{ns}$ & $\mathrm{ns}$ & $\mathrm{ns}$ & $\mathrm{ns}$ & & \\
\hline S2 & 48.4 & 0.002 & 0.0021 & ns & 0.01 & 0.05 & 0.01 & 0.04 & \\
\hline S3 & 44.5 & 0.0005 & 0.0006 & 0.03 & 0.003 & 0.02 & 0.003 & 0.02 & ns \\
\hline
\end{tabular}

susceptibility-resistance can be ruled out for the small sample included in this study.

Although only three slash pine parents were included in this study, heterogeneity in the relative resistance of slash pine was detected. Family S1 was as susceptible as the loblolly pine and F1 hybrid families. Slash pines on a site in South Carolina were reported to be highly susceptible to tip moth damage, but their susceptibility was associated with poor establishment on the field site. They became highly resistant after they were well established, which took about 2 years (Hood 1986). In this study, even though there was a substantial decrease in tip moth damage during the second year, the relative susceptibility of species and families was essentially constant over the 2-year course of the study based on leader incidence data (not shown). Thus, it appears that the heterogeneity in slash pine's resistance to tip moth damage in this study is intrinsic genetic variation that warrants further investigation.

This study was not designed to examine host selection in the female tip moth or to identify factors that help maintain her host range. Underlying mechanisms of these processes are largely unknown. However, helpful information could come from studies that associate chemical and physical traits of various genetic entities with susceptibility or resistance to tip moth damage. Such studies could utilize F1 interspecific crosses, backcrosses or resistant $\times$ susceptible intraspecific crosses.

\section{Conclusion}

The F1 hybrids of loblolly pine and slash pine were as susceptible to tip moth damage as was their susceptible loblolly parent. Their phenotypes supported a dominant or partially dominant mode of inheritance of susceptibility. One of the slash pine families was as susceptible to tip moth damage as were the susceptible loblolly and F1 hybrid pines, although slash pine in general has a high degree of resistance to tip moth damage. The two other slash pine families had significantly less damage.

\section{Acknowledgments}

The authors gratefully acknowledge Weyerhaeuser Company for the production of the plant material; the establishment, maintenance, and measurement of the field study; and for the open-pollinated loblolly pine seeds. Special thanks are extended to Steve Cade, Wilson Edwards, Jane Gregory Frampton, Clem Lambeth, Claire Williams, Paula Otto Zanker, and William E. (Joe) Miller for their valued contributions to this effort and to the former Union Camp Corporation for their contribution of the slash pine pollen and open-pollinated seeds. We gratefully acknowledge the support of the USDA Forest Service, Southern Institute of Forest Genetics, Saucier, Miss., and the USDA Cooperative State Research, Education, and Extension Service, National Research Initiative Competitive Grants Program. Thanks are also extended to the U.S. Department of Energy, Office of Energy Research, Office of Biological and Environmental Research, Environmental Sciences Division under the Minority College and Universities program administered by the Oak Ridge Institute for Science and Education.

\section{References}

Berisford, C.W. 1988. The Nantucket pine tip moth. In Dynamics of forest insect populations, patterns, causes, implications. Edited by A.A. Berryman. Plenum Press, New York. pp. 142-158.

Berisford, C.W., and Ross, D.W. 1990. Conifer shoot borers: a review of some major forest pests. Science in Forestry: IUFRO's Second Century, Proceedings of the XIX World Congress, 5-11 August 1990, Montréal, Que. Canadian IUFRO World Congress Organizing Committee, Hull, Que. Vol. 2. pp. 206-215.

Cade, S.C., and Hedden, R.L. 1987. Growth impact of pine tip moth on loblolly pine plantations in the Ouachita mountains of Arkansas. South. J. Appl. For. 11: 128-133.

Chapman, H.H. 1922. A new hybrid pine (Pinus palustris $\times$ Pinus taeda). J. For. 20: 729-734.

Frampton, L.J., and Huber, D.A. 1995. Clonal variation in four-yearold loblolly pine in coastal North Carolina. In Proceedings of the 23rd Southern Forest Tree Improvement Conference, Asheville, N.C. North Carolina State University - Industry Cooperative Tree Improvement Program, Raleigh, N.C. pp. 254-264.

Fritz, R.S., Nichols-Orians, C.M., and Brunsfeld, S.J. 1994. Interspecific hybridization of plants and resistance to herbivores: hypotheses, genetics, and variable responses in a diverse herbivore community. Oecologia, 94: 106-117.

Fritz, R.S., Roche, B.M., Brunsfeld, S.J., and Orians, C.M. 1996. Interspecific and temporal variation in herbivore responses to hybrid willows. Oecologia, 108: 121-129.

Grano, C.X., and Grigsby, H.C. 1968. Spraying southern pines not practical for tip-moth control. USDA For. Serv. Res. Note SO-77. 
Hatcher, L., and Stepanski, E.J. 1994. A step-by-step approach to using the SAS system for univariate and multivariate statistics. SAS Institute Inc., Cary, N.C. pp. 450-504.

Hedden, R.L., Richmond, J.A., Thomas, H.A., and Lashomb, J.H. 1981. Impact of pine tip moth on young loblolly pine biomass. In Proceedings of the 1st Biennial Southern Silvicultural Research Conference. Edited by P. Barnett. USDA For. Serv. Gen Tech. Rep. SO-34.

Hood, W.M. 1986. Hazard rating forest sites for pine tip moth, Rhyacionia spp., in northwestern South Carolina. Ph.D. dissertation, University of Georgia, Athens.

Hood, W.M., Berisford, C.W., and Hedden, R.L. 1985. Oviposition preferences of the Nantucket pine tip moth (Lepidoptera: Tortricidae) on loblolly and slash pine. J. Entomol. Sci. 20: 204206.

Ross, D.W., Birgerssson, W.G., Espelie, K.E., and Berisford, C.W. 1995. Monoterpene emissions and cuticular lipids of loblolly and slash pines: potential bases for oviposition preference of Nantucket pine tip moth. Can. J. Bot. 73: 21-25.

Stephen, F.M., Wallis, G.W., Colvin, R.J., Young, J.F., and Warren, L.O. 1982. Pine tree growth and yield: Influence of species, plant spacings, vegetation, and pine tip moth control. Ark. Farm. Res. 31: 10.

SAS Institute Inc. 1990. SAS/STAT user's guide, verison 6. 4th ed. SAS Institute Inc., Cary, N.C.

Wakeley, P.C. 1928. Preliminary observations on the pine tip moth (Rhyacionia frustrana Comst.) on southern pines. Proc. Int. Congr. Entomol. Trans. 4(2): 865-868.

Yates, H.O., III. 1966. Susceptibility of loblolly and slash pines to Rhyacionia spp. oviposition, injury and damage. J. Econ. Entomol. 59: 1461-1464.

Yates, H.O., III, and Beal, R.H. 1971. Nantucket pine tip moth. USDA For. Ser. For. Insect Dis. Leafl. 70. 